\title{
Newspaper Content Preferences- A Research on the Hindu and the Times of India
}

\author{
C.R.Mageshwar, R.Reshmaa, K.Mirunalini
}

\begin{abstract}
NewsPapers plays an important situation in everyday life. The present current world is inadequate aside from papers. It is our characteristic instinct to perceive what is occurring around us. No one needs to live in obliviousness. Subsequently papers have develop as stage and bundle of our life. The morning paper is as quintessential for a decent start to our day as the morning cup of tea. It is our scholarly breakfast and except if we go by means of the features we sense uneasy. What to talk about of the city-tenants, even the people dwelling in the towns are viewed as quick to go through the paper to understand what is happening on the planet. Subsequently, a paper is the major need of the successive individuals. In this way the examination is trotted on the perusers' substance material inclinations of The Hindu and The Times of India papers. A paper in the forefront society has excessively social and educative worth. It is a typical media of giving news close by with sees. Its significant point is to supply news, measurements with explicit perspectives through remarks, articles and publications. It is accordingly, alluded to as the 'individuals' college'. Various people anticipate explicit things from the paper. For example a venture man should know about the market drifts, a rancher is anxious to perceive the atmosphere report; a book peruser wants to think about the contemporary appearances. A paper fulfills them all like a private companion.
\end{abstract}

Keywords- newspaper, newsprint, news, information, advertisement, entertainment.

\section{INTRODUCTION}

A paper in the cutting edge society has incredible social and educative worth. It is a typical media of giving news alongside sees. Its chief point is to supply news, data with various perspectives through remarks, articles and publications. It is in this manner, called the 'individuals' college'. Various individuals anticipate various things from the paper. For instance a businessperson needs to realize the market slants, a rancher is anxious to know the climate forecast; a book peruser needs to think about the most recent appearances. A paper fulfills them all like a close companion.

A paper is a distribution containing news and data and publicizing, for the most part imprinted on minimal effort paper called newsprint. The fundamental reason for the paper is to let think about the world issues and their answers. Data that comes to us from paper all round the world is known as the news. It might be general or extraordinary intrigue, regularly distributed every day or week by week, month to month or fortnightly. Paper have four essential capacities to educate, to translate the news, to

\footnotetext{
Revised Manuscript Received on September 14, 2019.

Dr.C.R.Mageshwar, Department Head of IT \& E.Com, Sri Krishna Arts \& Science College, Coimbatore,Tamil Nadu, India.

R.Reshmaa, Assistant Professor of Commerce IT \& E.Com, Coimbatore,Tamil Nadu, India.

K.Mirunalini, Assistant Professor of Commerce IT \& E.Com, Coimbatore,Tamil Nadu, India.
}

give a help to perusers and to engage. These capacities clarifies what the paper does, and why individuals read paper.

(I) Newspaper help perusers become educated residents and settle on better choices by giving bunches of realities. Hard news tales about national, universal and neighborhood news, indispensable insights, climate, sports stories and scores and occasion schedules are instances of things that help educate perusers.

(ii) Some paper articles help decipher or clarify the importance of news to perusers. These accounts frequently incorporate the assessment of the essayist or paper the board. Publications, supposition segments, news examination and audits are a few models.

(iii) Newspaper stories give data that enables perusers to tackle their business, home, design, nourishment, diversion and every day living issues. Advertisements help with illuminating perusers about items and administrations. Hard news stories, include stories, classifieds promotions and show advertisements are things that give a service.

(iv) Some things in the paper are intended to interest or give delight to perusers. Highlight stories, funnies, riddles, motion pictures, and amusingness sections are amusement things.

(v) Perusing papers regular is must for the two understudies and grown-ups for development and illumination regardless of the class or field of their life

\section{LITERATURE REVIEW}

${ }^{1}$ Geetha (2012), The investigation upgraded the mentality of the perusers towards Dinakaran every day paper and furthermore the examination inspected the effect components influencing demeanor and fulfillment level of the paper. Test size of 150 supporters of Dinakaran Daily were utilized for the investigation. Basic rate strategy were utilized for measurable examination. The respondents are exceptionally happy with the substance of the

Dinakaran Daily, greater part $84 \%$ have superb sentiment about the accessibility of the paper, lion's share of the perusers are prepared to prescribe Dinakaran Daily to other people, the value inspired them to buy in Dinakaran Daily and $56 \%$ of the respondents are profoundly happy with fairmindedness of news in Dinakaran Daily.

${ }^{2}$ Rashmi Gupta and H V Gokhale (2012), In their examination endeavored to distinguish the fulfillment and impression of the clients with unique reference towards Nagpur area. The testing strategy utilized is basic arbitrary inspecting. An exhaustive and organized poll was utilized to 
gather the information. Among the four papers, The Hitavada and Lokmat appreciate high readership according to the review. This is on the grounds that the clients demonstrated high fulfillment level towards these papers' state inclusion, enhancements and sports inclusion.

${ }^{3}$ Sivakumar and Tamilselvan (2015), "Paper perusing propensities for undergrads: A contextual investigation of Kalaignar Karunanidhi Institute of Technology". The examination investigated the utilization of papers among undergrads. A poll and individual meetings were utilized for information gathering. The gathered information are arranged utilizing measurable table and rate. The investigation found that greater part of the understudies read paper in English language, the time spent is one to two hours in particular, the understudies read papers to get data and to improve their insight, most prevalent papers are The Hindu Tamil and The Hindu English and understudies like to peruse Headline News segments.

\section{RESEARCH METHODOLOGY}

Just perusers' of The Hindu and The Times of India have been taken as respondents for the examination. A pilot study was done before gathering the first information and dispersed to five perusers' of The Hindu paper and five perusers' of The Times of India paper. The examination region is limited to Coimbatore city in TamilNadu. The example size is 200 respondents out of whom were perusers' of The Hindu paper and 70 were perusers' of The Times of India paper. The determination of test depends on advantageous inspecting strategy. Essential information was utilized for the examination and it was gathered by methods for an organized poll produced for the investigation. The measurable instruments utilized here were Weighted Mean Rank, Kendalls' Co-Efficient of Concordance, and Mean Score.

\section{LIMITATIONS OF THE EXAMINATION}

The examination depends on advantageous inspecting which is a sort of non-irregular testing. Thus the restrictions of non-irregular examining are pertinent. The mentalities of the purchaser may change every once in a while. Henceforth the aftereffect of the task might be material for the current circumstance.

\section{ANALYSIS AND INTERPRETATION}

This segment manages investigation and elucidation of an examination on clients' recurrence of utilization and fulfillment in the utility of E-banking administrations in Coimbatore city. Proper factual devices were applied on the information gathered from the examples and introduced as tables under different headings:

\section{(I) Content Preferences of Main Newspaper}

So as to gauge and evaluate the relative inclination of the substance in the primary segment of the paper and the enhancement paper of the two driving papers taken for study, questions were encircled independently for the two. In the principle segment of the paper, the factors considered were business news, sports news, first page, publication, city news, national and worldwide news, state news, science and innovation and others.

Table 1 : Content preferences of Main Newspaper WEIGHTED MEAN RANK

\begin{tabular}{|c|c|c|c|c|}
\hline \multirow{2}{*}{$\begin{array}{l}\text { CONTENTS } \\
\text { OF MAIN } \\
\text { NEWSPAPER }\end{array}$} & \multicolumn{2}{|c|}{ THE HINDU } & \multicolumn{2}{|c|}{$\begin{array}{l}\text { THE TIMES } \\
\text { OF INDIA }\end{array}$} \\
\hline & $\begin{array}{l}\text { Weight } \\
\text { ed Mean }\end{array}$ & $\begin{array}{l}\text { Ra } \\
\text { nk }\end{array}$ & $\begin{array}{l}\text { Weight } \\
\text { ed Mean }\end{array}$ & $\begin{array}{l}\text { Ra } \\
\text { nk }\end{array}$ \\
\hline Business News & 4.97 & 5 & 5.09 & 6 \\
\hline Sports News & 5.39 & 7 & 5.24 & 7 \\
\hline First Page & 3.94 & 1 & 3.97 & 2 \\
\hline Editorial & 3.96 & 2 & 3.75 & 1 \\
\hline City News & 5.36 & 6 & 4.96 & 5 \\
\hline $\begin{array}{l}\text { National / } \\
\text { International } \\
\text { News }\end{array}$ & 4.25 & 3 & 4.77 & 3 \\
\hline State News & 4.39 & 4 & 4.89 & 4 \\
\hline $\begin{array}{cc}\text { Science } & \& \\
\text { Technology } & \end{array}$ & 6.18 & 8 & 6.43 & 9 \\
\hline Others & 6.56 & 9 & 5.89 & 8 \\
\hline
\end{tabular}

In perspective on the substance inclinations of primary papers, the principal page of The Hindu paper were given first significance while as if there should arise an occurrence of The Times of India paper publication segment were given due significance. If there should be an occurrence of The Hindu paper eighth position were given to the area science and innovation though different areas of The Times paper were given eighth position. Ultimately different segments of The Hindu paper were positioned ninth, however with the instance of The Times ninth position were given to the area Science and innovation.

\section{(II) Content Preferences of Supplement Newspaper}

In the enhancement papers, the factors considered were style and magnificence, motion pictures, cooking, wellbeing, religion, travel, training, classifieds and games and funny cartoons. The respondents were asked to rank these two inquiries in their request inclination giving position 1 to the exceptionally favored area, rank 2 to the following inclination and so on. The mean position were determined for the factors and exhibited in the accompanying areas to survey the near inclinations. 
Table 2 : Content preferences of Supplement Newspaper

\begin{tabular}{|c|c|c|c|c|}
\hline \multicolumn{2}{|c|}{ WEIGHTED MEAN RANK } \\
$\begin{array}{c}\text { THE HINDU } \\
\text { OF MAIN } \\
\begin{array}{c}\text { NEWSPAPE } \\
\text { R }\end{array}\end{array}$ & $\begin{array}{c}\text { THE Teight } \\
\text { OF INDIA } \\
\text { ed Mean }\end{array}$ & $\begin{array}{c}\text { Ra } \\
\text { nk }\end{array}$ & $\begin{array}{c}\text { Weight } \\
\text { ed Mean }\end{array}$ & $\begin{array}{c}\text { Ra } \\
\text { nk }\end{array}$ \\
\hline $\begin{array}{c}\text { Fashion \& } \\
\text { Beauty }\end{array}$ & 5.20 & 5 & 3.60 & 3 \\
\hline Movies & 3.98 & 4 & 3.57 & 2 \\
\hline Cuisine & 5.59 & 6 & 5.56 & 6 \\
\hline Health & 3.88 & 3 & 4.89 & 5 \\
\hline Religion & 6.68 & 9 & 6.41 & 7 \\
\hline Travel & 6.13 & 7 & 6.61 & 8 \\
\hline Education & 3.57 & 1 & 6.84 & 9 \\
\hline Classifieds & 3.74 & 2 & 3.23 & 1 \\
\hline $\begin{array}{c}\text { Games \& } \\
\text { Comic Strips }\end{array}$ & 6.22 & 8 & 4.29 & 4 \\
\hline
\end{tabular}

Whereas in view of the content preferences of supplement newspapers, first rank were given to the section education in case of The Hindu newspaper and classifieds were given rank in case of

The Times newspaper. Movies were given fourth rank in case of The Hindu newspaper and the section movies were ranked second in case of The Times newspaper.

(III) Content Preferences -Kendalls' Co-efficient of Concordance

This analysis is used for assessing agreement among raters. For this purpose the sections of Main Newspaper and Supplements Newspapers are rated in order to find the agreement between the raters of these two the newspapers

Table 3 : Level of Agreement in the Content

Preferences of Main and Supplement Newspaper

KENDALLS' CO-EFFICIENT OF CONCORDANCE

\begin{tabular}{|c|c|c|}
\hline \multirow{2}{*}{$\begin{array}{c}\text { MAIN } \\
\text { NEWSPAPER }\end{array}$} & $\begin{array}{c}\text { THE } \\
\text { HINDU } \\
\text { TIMES OF } \\
\text { INDIA }\end{array}$ \\
\cline { 2 - 3 } $\begin{array}{c}\text { SUPPLEMENT } \\
\text { NEWSPAPER }\end{array}$ & 0.121 & 0.093 \\
\hline
\end{tabular}

\section{FINDINGS \& RESULTS}

The content preferences of main newspapers, the first page of The Hindu newspaper were given first importance whereas as in case of The Times of India newspaper editorial section were given due importance whereas in the case of supplement newspaper first rank were given to the section education in case of The Hindu newspaper and classifieds were given ninth rank in case of The Times newspaper.

The level of agreement regarding the content preferences in the main newspaper between the readers of the Hindu is higher than the level of agreement between the readers of the Times of India whereas the content preferences in the supplement newspaper between the readers of The Times is higher than the level of agreement between the readers of The Hindu newspaper

\section{SUGGESTIONS}

\section{The Hindu}

1. The newspaper can focus on the special requirements of the student category to provide information in fulfilling their educational needs and to meet their career and employability prospects.

It should mainly focus on the sections of the supplements such as games and comics, religion and travel.

\section{The Times of India}

1. Revisions in the contents of the first page of the newspaper, the layout etc may be considered to increase satisfaction.

The newspaper should focus towards education, travel, religious aspects of news in the supplements.

\section{CONCLUSION}

In spite of the fact that The Hindu and The Times of India are known as the best driving English papers yet they are confronting a ton of rivalry. For this reason the investigation was taken to think about the readership design, content inclinations of understanding paper and to break down the degree of fulfillment of the perusers. The consequences of the examination will give fascinating bits of knowledge to both the papers as far as these qualities which they could use for their further headways

\section{REFERENCES}

1. N. Geetha (2012), "A Study On Readers Attitude Towards Dinakaran Daily News Paper With Special Reference To Tiruchengodu, Namakkal District", "International Journal of Management Research", Vol.1(2), pp.94-103.

2. Rashmi Gupta and H V Gokhale (2012), “An Analytical Study of Readers' Perception and Satisfaction Towards the Leading Newspapers of Nagpur Region", "Journal of Management Research”, Vol.11(3), pp.1-7.

3. Sivakumar and Tamilselvan (2015), "Newspaper Reading Habits of College Students: A Case Study of Kalaignar Karunanidhi Institute of Technology", "International Journal of Library Science and Research (IJLSR)", Vol.5(2), pp.31-36. 